\title{
Effects of the North Atlantic Oscillation on water temperature in southern Baltic coastal lakes
}

\author{
Józef Piotr Girjatowicz* \\ Institute of Marine Sciences, University of Szczecin, Wąska 13, 71-415 Szczecin, Poland
}

Received 27 November 2009; Accepted 6 October 2010

\begin{abstract}
The effects of the North Atlantic Oscillation (NAO) on water temperature (WT) in Lakes Jamno, Gardno, and Lebsko were studied between 1961 and 2000. Both sets of data (NAO and WT) consisted of monthly and seasonal values. Correlation and regression analyses were used and the relationships were tested for statistical significance (Fisher-Snedecor test, coefficients of correlation and determination). Positive and statistically significant (even at $\alpha=0.01$ ) relationships were demonstrated for the winter months (December, January, February and March) and in October. The strongest relationships were demonstrated for winter (December-February) in lakes Jamno and Gardno (correlation coefficients of 0.73 and 0.74). Extreme winters, particularly the very mild ones, tended to diminish the strength of the relationships. Very mild winters were characterised by relatively favourable solar (sunshine) conditions as well as high air and water temperatures, while the NAO Index values were relatively low. Relationships for spring (March-May) and summer (June-August) were not significant. In those seasons, the effects of atmospheric circulation (NAO) on WT were thus low, while the influences of solar factors were strong. Asynchronous relationships bear some predictive value, particularly when the predictive variable is the January NAO Index $\left(\mathrm{NAO}_{\mathrm{Jan}}\right)$. These relationships were significant at $\alpha=0.01$, out to April $\left(\mathrm{NAO}_{\mathrm{Jan}} v s\right.$. $\left.\mathrm{WT}_{\mathrm{Apr}}\right)$. Attention is also drawn to local factors (air temperature, geostrophic wind, solar conditions, and sea water intrusions into lakes) which affected the strength of the relationships investigated.
\end{abstract}

Key words: North Atlantic Oscillation / southern Baltic coastal lakes / water temperature

\section{Introduction}

Thermal conditions on the southern Baltic coast, like in the coastal zones almost throughout Europe, are dependent mainly on the activity of atmospheric pressure systems over the North Atlantic. The two stationary pressure centres, the Azores High and the Icelandic Low, generate air mass advection from the Atlantic onto the European continent. The intensity of the circulation depends on differences in atmospheric pressure between the two systems. In the early 20th century, Walker (1924) observed that the deep Icelandic Low corresponded to an unusually strong Azores High and vice versa, a shallow Icelandic Low corresponded to a weak Azores High. Walker referred to such synchronous pressure pulsation in those pressure centres as the North Atlantic Oscillation (NAO). The North Atlantic Oscillation has been considered to be a manifestation of teleconnections (Wallace and Gutzler, 1981) and belongs to the dominant northern

\footnotetext{
*Corresponding author: girjatjp@univ.szczecin.pl
}

hemisphere teleconnection system which is observable in each month (Barnston and Livezey, 1987). The NAO Index is defined as the difference between normalised Azores High and Icelandic Low pressures at the sea level. The index is one of the numerical indicators of hemispheric atmospheric circulation.

During the positive NAO phase which involves a large difference in the atmospheric pressure between the Azores High and the Icelandic Low, advection of air masses over the European continent produces a very intense zonal flow. Conversely, during the negative NAO phase, the advection is disturbed and proceeds mainly from longitudinal or eastern directions (Rogers and van Loon, 1979; Hurrell, 1995; Wibig, 2001). The advection of air mass from the Atlantic results in a distinct warming in winter and cool periods in summer over Europe. This is confirmed by correlations between the NAO Index and air temperature (Hurrell, 1996; Marshall et al., 1997; Marsz, 1999). The relationships show significant positive correlations. For example, Hurrell (1996) reported a highly significant correlation coefficient of $r=0.55 \quad(p<0.01)$ 
for the relationship between mean $\mathrm{NAO}_{\text {Dec-Mar }}$ indices and northern hemisphere $\left(20^{\circ}-90^{\circ} \mathrm{N}\right)$ air temperatures over 1934-1935 to 1994-1995. Similar values of correlation coefficients for air temperature and winter (Dec.Feb.) NAO Index in the central part of Estonia were reported by Nõges (2004, 2006). The North Atlantic Oscillation is associated very closely with the prevailing thermal conditions - not only in the lower part of the troposphere, but also in the entire troposphere (Wallace and Gutzler, 1981; Barnston and Livezey, 1987).

The NAO Index, as a measure of the intensity of advection of air masses from North Atlantic, is significantly correlated with ice conditions (Koslowski and Glaser, 1999; Maher et al., 2005; George, 2007). Koslowski and Glaser (1999) have demonstrated that heavy ice cover in the western Baltic accompanied the negative NAO phase which was exceptionally frequent during the "little ice age". On the other hand, during the positive NAO phases, manifested as intensive advection from the west, the ice cover is limited. This is confirmed by highly significant correlations between ice parameters and the NAO Index for the Schleswig-Holstein part of the German coast. The correlation coefficient of the relationship between the NAO Index and the mean ice cover index was 0.47 , the latter incorporating the compactness and thickness of ice cover, for six areas observed over 1871-1992 (error probability $<0.1 \%$; Koslowski and Loewe, 1994). Strong and significant relationships between the NAO Index and ice parameters were reported also from the Estonian Baltic coast. The correlation coefficients for the relationship between the number of days with ice, the date of ice break-up, and the maximum ice thickness were found to range from -0.34 to $-0.66, p<0.01$ (Jevrejeva, 2002). The correlation coefficient $(-0.54)$ between the NAO Index and the annual maximum ice extent in the Baltic (Omstedt and Chen, 2001) lies within that range as well. Stronger associations between the ice parameters mentioned and the NAO Index were found for shallow lakes (George et al., 2004b), and also for shallow sheltered areas of the southern Baltic coast. Correlation coefficients calculated for areas off river mouths and shallow coastal lagoons may exceed -0.70 and in coastal lakes may even exceed -0.80 (Girjatowicz, 2003), particularly with respect to the number of days with ice. Trends in ice conditions in lakes and rivers in the northern hemisphere were reported by Magnuson et al. (2000), whereas Alenius and Makkonnen (1981), Kożuchowski (1996), Jevrejeva et al. (2004), and Jaagus (2006) described corresponding trends in the Baltic Sea.

The North Atlantic Oscillation affects hydrological and meteorological conditions and also a number of other processes and ecological phenomena (Gerten and Adrian, 2001; D'Odorico et al., 2002; Straile et al., 2003). According to Straile et al. (2003), physical effects of NAO include changes in river flow rate, lake temperature profile, phenology of ice cover, and lake water level. Those parameters in turn affect the chemistry and biology of aquatic ecosystems. The strong influence of the winter NAO Index on meteorological conditions, physical, and subsequently on chemical conditions of lake waters has also been reported by George et al. (2004b) and by Weyhenmeyer (2004). The relationship between the NAO and variations in surface temperature, storms and precipitation, as well as variations within ecosystems and how this affects the economy has been described by Hurrell et al. (2003), and also by George et al. (2004a).

Significant correlations between the North Atlantic Oscillation and water temperature for Austrian lakes were reported by Livingstone and Dokulil (2001), Straile et al. (2003), and by Maher et al. (2005). The effects of seasonal NAO indices on the surface temperature in eight lakes of the northern piedmont region of Austria have been reported in a study conducted by Livingstone and Dokulil (2001). They found that the spatial coherence of the surface water temperature in the lakes, from autumn until spring, was associated with the dominant weather type controlled by large-scale climatic processes above the northern Atlantic. However, regional processes are more important in summer. The effects of the North Atlantic Oscillation Index on the temperature were most pronounced in lower-lying lakes where ice cover is not frequent and persists for a short time. Significant correlations between water temperature and NAO Index have also been reported from other lakes of the northern hemisphere (George et al., 2004b; Maher et al., 2005). Water temperature trends in some lakes of the northern hemisphere were described by Peeters and Livingstone (2002), Livingston (2003), and Arhonditsis and Brett (2004).

The North Atlantic Oscillation Index, which is strongly correlated with air temperature and ice conditions, should also significantly affect the water temperature in coastal lakes of the southern Baltic Sea coast. This was corroborated by the preliminary studies in the southern Baltic. The highest NAO Index-water temperature correlation coefficients for certain winter months ranged from 0.68 to 0.78 (Marsz and Styszyńska, 2003). It should be expected that strong correlations between the NAO Index and water temperature will occur in the coastal lakes also in winter (December-February). Some significant asynchronous correlations should be expected as well, particularly with respect to the shortest (1-month-long) time intervals.

This study aimed at exploring relationships between the NAO Index and the surface water temperature in southern Baltic coastal lakes indifferent months and seasons of the year. The synchronous relationships explored include the variables (dependent and independent) concerning the same months and/or seasons. On the other hand, asynchronous relationships occur when the NAO Index variable (the independent variable) precedes water temperature (the dependent variable) by one or more months. Attention is being drawn also to local factors such as air temperature, geostrophic wind, solar conditions, and sea water inflows into the lakes; those factors are regarded as potentially important for the strength of the relationships studied. Significant correlations, particularly the asynchronous ones, in the lakes 


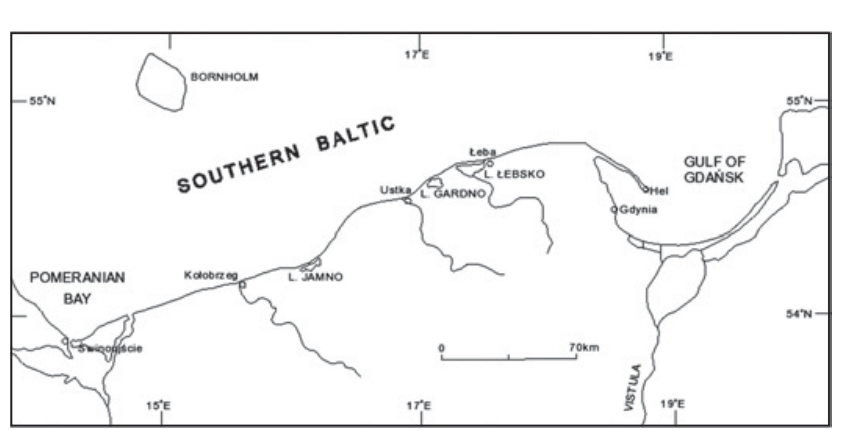

Fig. 1. Location of coastal lakes and meteorological stations on the southern Baltic Sea coast.

studied can involve a prognostic aspect. The lakes studied are the largest lakes at the Baltic Sea coast.

\section{Morphometric and hydrological- meteorological conditions in the lakes studied}

The coastal lakes were formed as a result of sea level rise and inundation of low-lying areas (e.g., Lake Jamno) or as a result of sea bays having been cut off from the sea by sandy spits shaped by waves, currents, and the wind (e.g., Lakes Gardno and Lebsko; Fig. 1). The lakes are large and have a surface area exceeding $20 \mathrm{~km}^{2}$. The Lebsko is the largest of the three lakes with a length of over $16 \mathrm{~km}$, and a width of $8 \mathrm{~km}$. The surface areas exceed $70 \mathrm{~km}^{2}$ (Jańczak, 1997). These are very shallow lakes. The maximum depth is 3-6 $\mathrm{m}$, and the average depth does not exceed $2 \mathrm{~m}$. Full morphometric data of these lakes are represented in the Table 1 . The lakes are located in mostly marshy areas where the water level is a few tens of centimetres above sea level (Majewski, 1972; Choiński, 1995; Kondracki, 1998). These are the lakes in which the water column undergoes multiple mixing (circulation) within an annual cycle (Choiński, 1995).

The thermal regime of these lakes is strongly dependent on climatic conditions. The annual trend of annual monthly mean temperatures of water and air is sinusoid, the differences between the temperatures being low and averaging about $1{ }^{\circ} \mathrm{C}$. It is only in summer and winter months that the differences increase and range from 1 to $2.5^{\circ} \mathrm{C}$. The lowest annual monthly mean water temperatures of about $1{ }^{\circ} \mathrm{C}$ are typical of January, while the highest temperature, recorded in July, exceeds $18^{\circ} \mathrm{C}$ (Table 2). Slightly higher water temperatures are recorded in the western part (Lake Jamno) than in the eastern part of the coast (lakes Gardno and Łebsko). The average seasonal water temperatures (WT) of the lakes are also slightly higher in the western than in the eastern part of the coast. The highest seasonal WT (June-August) reaches $20.4^{\circ} \mathrm{C}$ in Lake Jamno; the average temperatures range from $17.3{ }^{\circ} \mathrm{C}$ (Lake Gardno) to $18{ }^{\circ} \mathrm{C}$ (Lake Jamno). However, the highest monthly WT $\left(22.1^{\circ} \mathrm{C}\right)$ was recorded in July 1994 in Lake Lebsko, while the lowest $\left(0.0^{\circ} \mathrm{C}\right)$ - in February 1991 - was recorded in Lake Jamno (Table 2). Similarly, air temperatures (except for summer) are slightly higher in the western than in the eastern part of the coast (Table 1). The difference is caused mainly by the climatic conditions with warmer thermal regime occurring in the western part, compared with the eastern part of the coast (Wiszniewski, 1973; Kozłowska-Szczęsna, 1997; Lorenc, 2005).

These coastal lakes are the shallowest areas along the southern Baltic coast and therefore experience the most severe ice conditions. The first ice normally appears as early as the beginning of December in the eastern part of the coast (Lake Łebsko and Lake Gardno), but disappears in the third pentade of March. The ice season lasts about 100 days, 85 of which falls for the ice season in Lake Jamno. The lakes are ice-bound almost every year. The ice cover remains for the longest period of time (65 days) in the shallowest lake (Lake Gardno); it stays for shorter periods of time on Lake Jamno (57 days) and on Lake Łebsko (58 days; Table 1). Fast ice clearly dominates $(80 \%)$ over floating ice $(20 \%$; Girjatowicz, 2003$)$. The mean number of days with ice ranges from 68 (Lake Jamno) to 77 (Lake Gardno), with the mean maximum ice thickness ranging from 22 to $24 \mathrm{~cm}$, respectively (Table 1).

The coastal lakes studied are connected to the sea by straits formed by river mouths. The lakes may experience incursions of sea water during some periods (shoreward storms from $\mathrm{W}, \mathrm{NW}$, and $\mathrm{N}$ ). Riverine water discharges are at their most intensive during winter-spring (Szmidt, 1967; Mikulski, 1970). In summer and during autumnwinter, the discharge from Lake Jamno, and also that from Lake Gardno, may be blocked by marine-derived sediments. The level of these lakes increases considerably as a result of the lack of outflow from the riverine discharge. However, the highest water levels in the lakes are associated with sea water inflows (Mikulski, 1964; Cyberski, 1984; Majewski, 1987). The extremely high water levels exceed $80 \mathrm{~cm}$ above the mean levels. On the other hand, the lowest levels are approximately $50 \mathrm{~cm}$ lower than the mean levels and are then lower than the mean sea level. Extreme amplitudes of the water level exceed $130 \mathrm{~cm}$ (Table 1). However, the average water levels in these lakes are only slightly higher (by $6-20 \mathrm{~cm}$ ) than the average sea level $(500 \mathrm{~cm})($ Table 1$)$.

Sea water inflows affect the salinity and temperature of the lakes, particularly in the vicinity of the straits (Majewski, 1972; Drwal and Cieśliński, 2007). Colder sea water cools the water in the lakes in spring-summer. The reverse situation is true in autumn-winter when the warmer sea water warms the water in the lakes (Cyberski and Jędrasik, 2000; Girjatowicz, 2006). Due to their close proximity to the sea shore (about $1 \mathrm{~km}$ ), the lakes are affected by the air advecting from over the sea. This advection produces a cooling effect in spring-summer, while a warming effect is experienced in autumn-winter.

\section{Materials and methods}

The study was based on archived data on surface water temperature of lakes Jamno, Gardno, and Łebsko. 
Table 1. Morphometric and bathymetric data, mean air temperatures, mean parameters of ice conditions, mean and extreme values of water levels in coastal lakes (Jamno, Gardno and Łebsko) of the southern Baltic Sea.

\begin{tabular}{|c|c|c|c|c|c|c|}
\hline Lakes & \multicolumn{2}{|c|}{ Latitude } & Longitude & \multicolumn{2}{|c|}{$\begin{array}{c}\text { Length of } \\
\text { maximum }(\mathrm{km})\end{array}$} & $\begin{array}{c}\text { Width of } \\
\text { maximum }(\mathrm{km})\end{array}$ \\
\hline$\overline{\text { Jamno }}$ & \multicolumn{2}{|c|}{$54^{\circ} 16.7^{\prime} \mathrm{N}$} & $16^{\circ} 08.3^{\prime} \mathrm{E}$ & \multicolumn{2}{|c|}{10.10} & 3.40 \\
\hline Gardno & \multicolumn{2}{|c|}{$54^{\circ} 39.4^{\prime} \mathrm{N}$} & $17^{\circ} 07.1^{\prime} \mathrm{E}$ & \multicolumn{2}{|c|}{6.85} & 4.73 \\
\hline \multirow[t]{2}{*}{ Łebsko } & \multicolumn{2}{|c|}{$54^{\circ} 42.8^{\prime} \mathrm{N}$} & $17^{\circ} 24.7^{\prime} \mathrm{E}$ & \multicolumn{2}{|c|}{16.36} & 7.60 \\
\hline & \multirow{2}{*}{$\begin{array}{c}\text { Elevation } \\
\text { (m a.s.1.) }\end{array}$} & $\begin{array}{c}\text { Surface } \\
\text { area }\left(\mathrm{km}^{2}\right)\end{array}$ & $\begin{array}{l}\text { Volume } \\
\left(\mathrm{km}^{3}\right)\end{array}$ & $\begin{array}{c}\text { Average } \\
\text { depth (m) }\end{array}$ & $\begin{array}{l}\text { Maximum } \\
\text { depth (m) }\end{array}$ & $\begin{array}{l}\text { Length of the } \\
\text { shore-line }(\mathrm{km})\end{array}$ \\
\hline Jamno & & 22.4 & 0.032 & 1.4 & 3.9 & 28.3 \\
\hline Gardno & $\begin{array}{l}0.1 \\
03\end{array}$ & \multirow{2}{*}{$\begin{array}{l}24.08 \\
71.4\end{array}$} & 0.031 & 1.3 & 2.6 & 23.3 \\
\hline Łebsko & 0.3 & & 0.118 & 1.6 & 6.3 & 55.9 \\
\hline \multicolumn{7}{|c|}{ Air temperatures $\left({ }^{\circ} \mathrm{C}\right)^{*}$} \\
\hline & Dec.-Feb. & Mar.-May & Jun.-Aug. & Sept.-Nov. & Jan.-Dec. & $\begin{array}{c}\text { Annual } \\
\text { amplitude }\end{array}$ \\
\hline Jamno & 0.2 & \multirow{2}{*}{$\begin{array}{l}6.3 \\
6.1\end{array}$} & 16.0 & 9.2 & 7.9 & 17.3 \\
\hline Gardno & 0.2 & & 16.1 & 9.1 & 7.8 & 17.4 \\
\hline Łebsko & 0.2 & 6.1 & 16.2 & 9.1 & 7.8 & 17.4 \\
\hline Ice cond & & & & & & \\
\hline & First ice & Last ice & & $\begin{array}{c}\text { Days } \\
\text { with ice }\end{array}$ & $\begin{array}{l}\text { Days with } \\
\text { ice cover }\end{array}$ & $\begin{array}{l}\text { Maximum ice } \\
\text { thickness }(\mathrm{cm})\end{array}$ \\
\hline$\overline{\text { Jamno }}$ & 11 Dec. & 7 Mar. & & 68 & 57 & 22 \\
\hline Gardno & 5 Dec. & 12 Mar. & & 77 & 61 & 24 \\
\hline Łebsko & 4 Dec. & 11 Mar. & & 74 & 58 & 23 \\
\hline Water le & & & & & & \\
\hline & & Minimum & & Mean & & Maximum \\
\hline Jamno & & $465 \mathrm{~cm} 25$ Mar. 1972 & & $515 \mathrm{~cm}$ & & $598 \mathrm{~cm} 20$ Jan. 1983 \\
\hline Gardno & & $470 \mathrm{~cm} 6$ Jun. 1978 & & $520 \mathrm{~cm}$ & & $604 \mathrm{~cm} 21$ Jan. 1983 \\
\hline Łebsko & & $458 \mathrm{~cm} 20 \mathrm{Feb} .1963$ & & $506 \mathrm{~cm}$ & & $588 \mathrm{~cm} 1$ Dec. 1978 \\
\hline
\end{tabular}

*1947-2000, **1960/1961-1999/2000, ***1956-1983.

Table 2. Mean and extreme monthly values of water temperature $\left({ }^{\circ} \mathrm{C}\right)$ in coastal lakes of the southern Baltic Sea in months, season and year (1961-2000).

\begin{tabular}{|c|c|c|c|c|c|c|c|c|c|}
\hline \multirow[b]{2}{*}{ Months } & \multicolumn{3}{|c|}{ Lake Jamno } & \multicolumn{3}{|c|}{ Lake Gardno } & \multicolumn{3}{|c|}{ Lake Łebsko } \\
\hline & Min. & Mean & Max. & Min. & Mean & $\overline{\text { Max. }}$ & Min. & Mean & Max. \\
\hline Jan. & 0.1 & 1.2 & 3.4 & $\begin{array}{ll}0.1 \\
\end{array}$ & 1.0 & 3.1 & 0.2 & 1.3 & 4.7 \\
\hline Feb. & 0.0 & 1.5 & 5.0 & 0.1 & 1.1 & 4.5 & 0.1 & 1.4 & 4.2 \\
\hline Mar. & 0.3 & 3.0 & 7.5 & 0.1 & 2.4 & 5.2 & 0.2 & 2.8 & 5.6 \\
\hline Apr. & 4.2 & 7.1 & 9.2 & 3.7 & 6.6 & 9.4 & 4.7 & 7.2 & 9.6 \\
\hline May & 8.8 & 12.8 & 17.4 & 9.2 & 12.4 & 15.3 & 10.1 & 12.7 & 15.5 \\
\hline Jun. & 14.1 & 17.0 & 19.1 & 14.1 & 16.4 & 18.6 & 14.9 & 16.6 & 18.8 \\
\hline Jul. & 15.6 & 18.6 & 21.5 & 15.1 & 18.1 & 20.8 & 15.7 & 18.3 & 22.1 \\
\hline Aug. & 15.9 & 18.2 & 21.8 & 15.8 & 17.4 & 20.4 & 15.9 & 17.8 & 20.7 \\
\hline Sept. & 12.2 & 14.1 & 16.9 & 11.2 & 13.4 & 15.8 & 11.9 & 13.6 & 15.5 \\
\hline Oct. & 5.4 & 9.3 & 12.2 & 6.1 & 8.8 & 11.5 & 7.1 & 9.2 & 11.1 \\
\hline Nov. & 2.2 & 4.4 & 6.5 & 1.9 & 4.3 & 6.8 & 2.2 & 4.7 & 7.5 \\
\hline Dec. & 0.2 & 1.7 & 4.9 & 0.2 & 1.7 & 4.3 & 0.5 & 2.0 & 3.8 \\
\hline Dec.-Feb. & 0.3 & 1.5 & 3.2 & 0.1 & 1.3 & 2.9 & 0.4 & 1.5 & 3.1 \\
\hline Mar.-May & 4.5 & 7.6 & 10.0 & 4.8 & 7.1 & 9.2 & 5.6 & 7.5 & 9.7 \\
\hline Jun.-Aug. & 15.9 & 18.0 & 20.4 & 15.7 & 17.3 & 18.8 & 15.8 & 17.6 & 19.3 \\
\hline Sept.-Nov. & 7.6 & 9.3 & 11.2 & 7.2 & 8.8 & 10.5 & 7.9 & 9.2 & 10.3 \\
\hline Year & 7.7 & 9.1 & 10.6 & 7.7 & 8.6 & 9.7 & 7.7 & 9.0 & 10.1 \\
\hline
\end{tabular}


The temperature data are monthly means for the period 1961-2000, contained in the data base of the Institute of Meteorology and Water Management (IMWM) in Gdynia (Poland). The monthly, seasonal, and annual means and extreme values are given in Table 2; with the location of the lakes shown in Figure 1. The water temperature was taken from piers of fishing havens at 12 GMT with a $\mathrm{Hg}$ thermometer $\left(0.1^{\circ} \mathrm{C}\right.$ accuracy $)$ in the surface water layer and at $0.5 \mathrm{~m}$ depth. When the lakes were ice-bound, the water temperature was taken either from an air hole or from a lead in the ice.

Mean monthly values of the NAO Index used in this study are those available in the Internet on the web page of the East Anglia University in Norwich (United Kingdom; www.cru.uea.ac.uk/ftpdata/nao.dat). NAO is defined as the difference between normalised atmospheric pressure values in Gibraltar (the Azores High) and in Reykjavik (the Icelandic Low; Jones et al., 1997). Normalisation was performed by subtracting individual pressure values from the mean and dividing the value obtained by the standard deviation. Seasonal and annual mean NAO Index values and water temperature were calculated from the respective monthly mean values over the period 1961-2000. Winter, spring, summer, and autumn in this study correspond with the periods of December-February, March-May, June-August, and September-November, respectively.

Additional meteorological data, in the form of monthly mean air temperatures and sums of total radiation in Gdynia (Environmental..., 1999), were used to explain certain major discrepancies between water temperature and NAO Index in some extreme winters. Directions of the geostrophic wind, drawn from the calendar of local indices of atmospheric circulation (Miętus, 2000) were also used. The calendar contains numerical values of meridional and zonal components of the geostrophic wind vector for the southern Baltic, i.e., diel value of the geostrophic wind vector set at the centre of gravity of a triangle $\left(55^{\circ} 22^{\prime} \mathrm{N}\right.$; $\left.17^{\circ} 08^{\prime} \mathrm{E}\right)$ formed by the location of three synoptic stations: Świnoujście, Hel, and Visby (Gotland) (Miętus, 1994). The components, arc tan-transformed, were used to determine directions of advection, labelled with letters commonly found in the wind rose (N, NE, E, SE, S, SW, $\mathrm{W}, \mathrm{NW}$ ). Frequencies of those directions (as number of days) in each month were calculated subsequently.

Correlation and regression analyses were used to determine and explore relationships between the NAO Index and lake surface water temperature in months, seasons, and years. Linear regression equations were developed, whereby water temperature was the dependent variable $(y)$ and the NAO Index served as the independent variable $(x)$. Statistical significance of the relationships was tested with the Fisher-Snedecor test $(\mathrm{F})$ at significance levels of $\alpha=0.05$ and $\alpha=0.01$, the respective error risks being thus set at $5 \%$ and $1 \%$. The strength of the relationship between the two variables was determined from correlation coefficients $(r)$, the correspondence between the variables is described by the coefficient of determination $\left(R^{2} \cdot 100 \%\right)$. The latter is interpreted as a percentage of the total variation of the dependent variable (y) that is explained by the variation in the independent variable $(x)$. The $99 \%$ confidence interval is shown for linear relationships presented in the orthogonal coordinate system.

\section{Synchronous relationships}

Positive and significant relationships between the monthly mean NAO Index values and the monthly mean water temperature (WT) in the coastal lakes were observed primarily in winter months, i.e. from December to March. In addition, the relationships were significant, even at $\alpha=0.01$, in October for Lake Gardno and Lake Lebsko (Table 3). The relationships in January and February were clearly stronger than those in March, October, and December. The strongest relationship, with a correlation coefficient of 0.714 , was recorded in Lake Gardno in February (Table 3). As indicated by the coefficient of determination, the NAO Index variation in that case explained $51 \%$ of the variation in the water temperature. Values of correlation coefficients for the relationships involving monthly means recorded in individual lakes showed no distinct changes from west to east.

The weakest and non-significant relationships were typical of summer months with the coefficients of correlation and regression being mostly negative.

The relationships between the NAO Index and water temperature were stronger in winter months taken together than in individual months. The strongest correlations were revealed in winter (December-February), the weakest correlations occurring in spring (March-May). The winter correlation coefficients exceeded 0.70 (Table 3). The highest winter correlation coefficient $(0.741)$ was shown by Lake Gardno. The corresponding coefficients of determination indicated that $55 \%$ and $53 \%$ of the water temperature variation in Lake Gardno and Lake Jamno were explained by the variation in $\mathrm{NAO}_{\text {Dec-Feb }}$ (Figs. 2a and $2 \mathrm{~b}$ ). On the other hand, the variation in $\mathrm{NAO}_{\text {Dec-Feb }}$ explained $50 \%$ of the corresponding variation in Lake Lebsko (Fig. 2c). The relationships are illustrated by graphs plotted in the orthogonal coordinate system (Fig. 2). In addition to showing regression lines and their equations, Figure 2 contains also the $99 \%$ confidence limits. Positive values of both the regression and correlation coefficients demonstrate an increase in the NAO Index to be accompanied by increasing water temperature. A one unit increase in the $\mathrm{NAO}_{\mathrm{Dec}-\mathrm{Feb}}$ index produces an $0.38,0.35$, and $0.37^{\circ} \mathrm{C}$ increase in the December-February mean water temperature in Lakes Jamno, Gardno, and Lebsko, respectively (Fig. 2). It can thus be concluded that, in winter, the warm air masses advected from over the ocean onto the continent (NAO) exert the most important effect on the water temperature variation in the lakes studied.

In addition to winter (December-February), some lakes showed significant relationships to occur also in autumn (September-November) and summer (June- 
Table 3. Linear correlation coefficients for specific periods of the North Atlantic Oscillation Index with water temperature of coastal lakes of the southern Baltic Sea in months, season and year (1961-2000).

\begin{tabular}{lccc}
\hline Months & Jamno & Gardno & Łebsko \\
\hline Jan. & $0.710^{* *}$ & $0.640^{* *}$ & $0.688^{* *}$ \\
Feb. & $0.601^{* *}$ & $0.714^{* *}$ & $0.667^{* *}$ \\
Mar. & $0.419^{* *}$ & $0.434^{* *}$ & $0.414^{* *}$ \\
Apr. & -0.170 & -0.173 & -0.006 \\
May & 0.204 & 0.170 & -0.028 \\
Jun. & -0.241 & -0.232 & -0.167 \\
Jul. & -0.126 & -0.118 & -0.033 \\
Aug. & -0.066 & -0.102 & 0.044 \\
Sept. & 0.284 & 0.238 & 0.120 \\
Oct. & $0.352^{*}$ & $0.494^{* *}$ & $0.505^{* *}$ \\
Nov. & 0.212 & 0.259 & 0.310 \\
Dec. & $0.475^{* *}$ & $0.491^{* *}$ & $0.403^{* *}$ \\
& & & \\
Dec.-Feb. & $0.725^{* *}$ & $0.741^{* *}$ & $0.705^{* *}$ \\
Mar.-May & 0.179 & 0.076 & 0.041 \\
Jun.-Aug. & -0.295 & $-0.330^{*}$ & -0.070 \\
Sept.-Nov. & 0.196 & $0.355^{*}$ & $0.312^{*}$ \\
& & & \\
Year & $0.438^{* *}$ & $0.430^{* *}$ & $0.471^{* *}$ \\
\hline
\end{tabular}

*Values significant at the level $\alpha=0.05$.

$* *$ Values significant at the level $\alpha=0.01$.

August). Significant relationships were revealed in Lake Gardno and Lake Lebsko at $\alpha=0.05$. On the other hand, significant relationships in summer were revealed in Lake Gardno only. The lake is the shallowest of the three, hence it rapidly responds to thermal factors. The summer correlation coefficients were negative (Table 3). They are a signal that an increase in the $\mathrm{NAO}_{\text {Jun-Aug }}$ Index is accompanied by a decrease in $\mathrm{WT}_{\mathrm{Jun}-\text { Aug }}$. During that season, the polar-maritime air masses advecting from the west onto the heated European continent cool it down and increase the cloud cover, thus reducing the solar radiation and decreasing the water temperature. Therefore the NAO Index, which reflects the intensity of advection of the Atlantic air masses, will be negatively, albeit weakly, correlated with water temperature in summer.

Some data points are located far away from the regression line (Fig. 2). A large dispersion of these points occurred when the NAO Index values were close to zero and mostly ranged from -1 to 1 . Within that range, when the zonal inflow of air masses is weakened, fairly contrasting thermal conditions can appear, strengthened by local factors (local air pressure systems, winds, solar conditions, etc.). At this juncture, considerable warming or cooling can occur. At identical values of the NAO Index, the air masses may be advected from, e.g., the north or from the south; contrasting solar or cloudiness situations can also occur. The southerly geostrophic wind is usually accompanied by an increase in the air temperature, whereas a drop in the air temperature occurs when the wind blows from the north.

A large scatter of data points occurred mostly in extreme winters, particularly in the very mild ones
(1974-1975, 1987-1988, 1989-1990, 1997-1998). An example is furnished by the data from the very mild winter of $1997 / 1998$, particularly in Lake Lebsko (NAO $=0.65$, $\mathrm{WT}=2.9^{\circ} \mathrm{C}$; Fig. 2c). The water temperature was high, compared with the relatively low value of the NAO Index during that winter, particularly in the eastern part of the area of study. For example, the January water temperature anomaly $(\triangle \mathrm{WT})$ in Lake Lebsko was as high as $1.6^{\circ} \mathrm{C}$, while the NAO Index was as low as -0.28 (Fig. 3). This relatively large discrepancy between the NAO Index and the water temperature in the winter of 1997-1998, particularly in January, may be explained not only by a weak advection of air masses from the Atlantic, but also by effects of relatively high air temperature which could have been induced by local conditions, e.g., solar factors. However, it should be borne in mind that in winter (December-February), the air temperature has a decisive influence on the water temperature in the lakes studied (limited effects of solar factors). The parameters in question (WT, AT) are strongly correlated, the correlation coefficients being higher than 0.80 . The air temperature anomaly $(\triangle \mathrm{AT})$ at Łeba was as high as $3.6^{\circ} \mathrm{C}$ (Fig. 3). In addition, the direction of the geostrophic wind $(\mathrm{G})$ over the southern Baltic in January 1998 clearly indicated the domination of air masses advecting from the western sector $(\mathrm{SW}+\mathrm{W}+\mathrm{NW}=20$ days, i.e., $65 \%)$ over the advection from the eastern sector $(\mathrm{NE}+\mathrm{E}+\mathrm{SE}=4$ days, i.e., 13\%; Fig. 3). Similarly, the southerly wind was quite frequent (about 30\%) that winter (Environmental..., 1999). It should be borne in mind that, in winter, the geostrophic wind from the western sector and from the south (from the Mediterranean Sea basin) is associated with an inflow of usually warm air, while advection of a cool water mass usually accompanied the geostrophic wind from the eastern sector and from the north. During that winter, the relatively high water temperatures in the lakes could be also produced by influxes of the relatively warm sea water intruding via canals connecting the lakes with the Baltic. The sea water temperature in December and January was higher than that in Lake Lebsko by $1.3^{\circ} \mathrm{C}\left(3.6\right.$ vs. $\left.2.3^{\circ} \mathrm{C}\right)$ and by $0.5^{\circ} \mathrm{C}\left(3.4\right.$ vs. $\left.2.9^{\circ} \mathrm{C}\right)$, respectively, and was by $0.9^{\circ} \mathrm{C}$ lower $\left(2.5\right.$ vs. $\left.3.4{ }^{\circ} \mathrm{C}\right)$ in February. During the period between DecemberFebruary, winds blowing from the north-western sector $(\mathrm{W}+\mathrm{NW}+\mathrm{N}$; Fig. 3) which enhanced sea water intrusions were relatively frequent (53 days, i.e., 58.9\%). It should be noted that the wind from this sector blows towards the shore and produces surges along the southern Baltic coast.

The relatively high air and water temperatures in the winter of 1997-1998 could have been, to some extent, influenced by solar factors (cloudiness/sunshine and solar radiation intensity). According to data collected by the Institute of Meteorology and Water Management (Environmental..., 1999), the deviation of the total radiation sum over December-February from the multiannual mean was positive and amounted to $512 \mathrm{~J} . \mathrm{cm}^{-2}$. The very mild winters were also characterised by a mean cloudiness which was slightly lower $(7 / 10)$ than that 

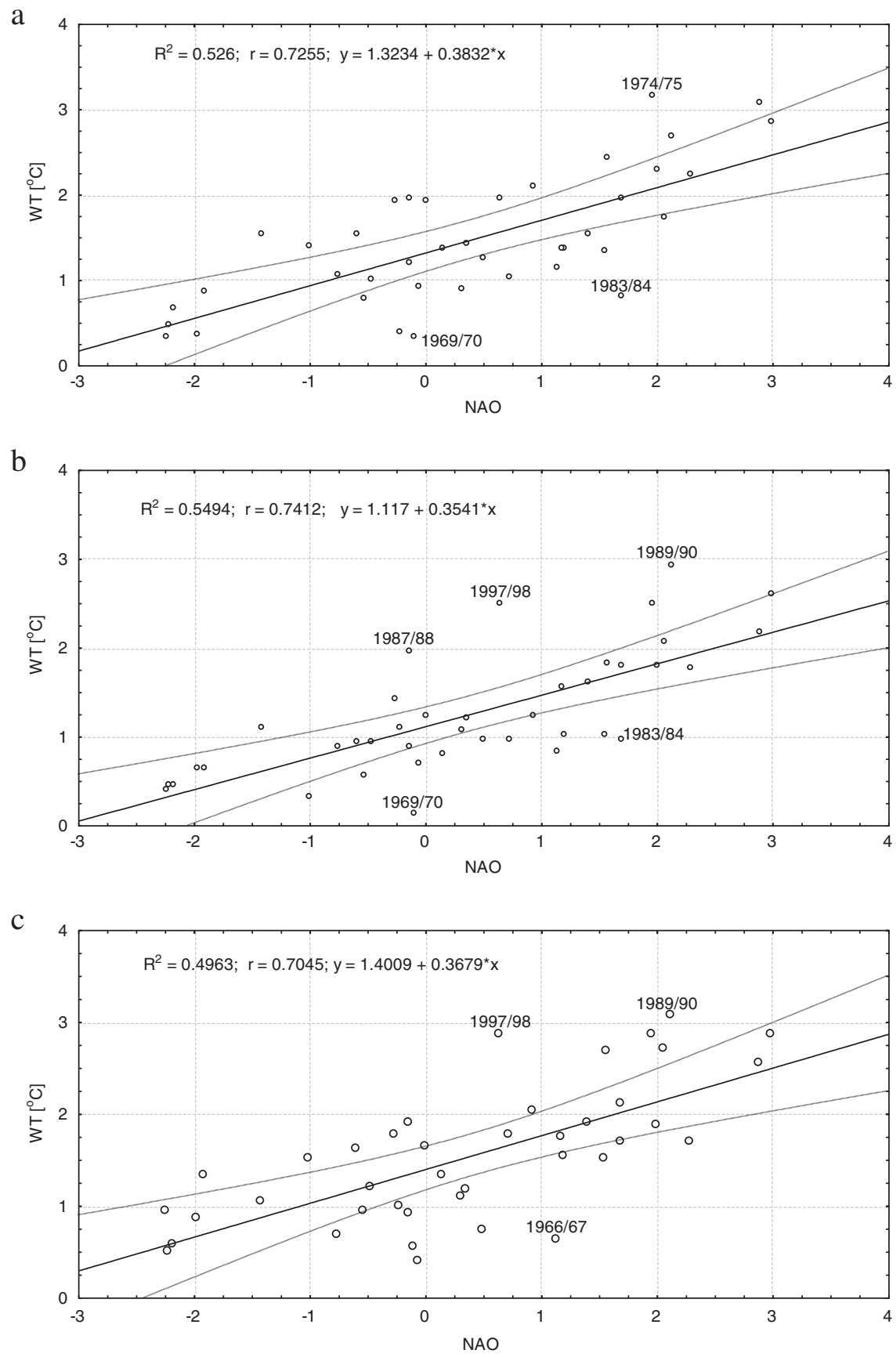

Fig. 2. The relationships between water temperature (WT) in lakes: Jamno (a), Gardno (b), Lebsko (c) with the North Atlantic Oscillation Index in winter (Dec.-Feb.; 1960/1961-1999/2000).

recorded in the remaining winters $(7.5 / 10)$ which showed relatively low water temperatures (Fig. 2).

\section{Asynchronous relationships}

Relationships between the NAO Index and water temperature over non-simultaneous (i.e., asynchronous) periods of time, in terms of both monthly and seasonal values, were weaker than those revealed for synchronous periods. Like the synchronous relationships, the asynchronous ones were statistically significant mainly in winter (Table 4). The NAO Index was used as an independent (predictive) variable at time lags (preceding the water temperatures) of one month, two months, etc., until the disappearance of significant correlations. The longer the time lag, the weaker the correlations; eventually, they become non-significant. The longest predictive length of time producing significant correlations involved the relationships with the January value of the predictive variable $\left(\mathrm{NAO}_{\text {Jan }}\right.$; Table 4). Significance of those relationships disappeared when the time lag was four months 


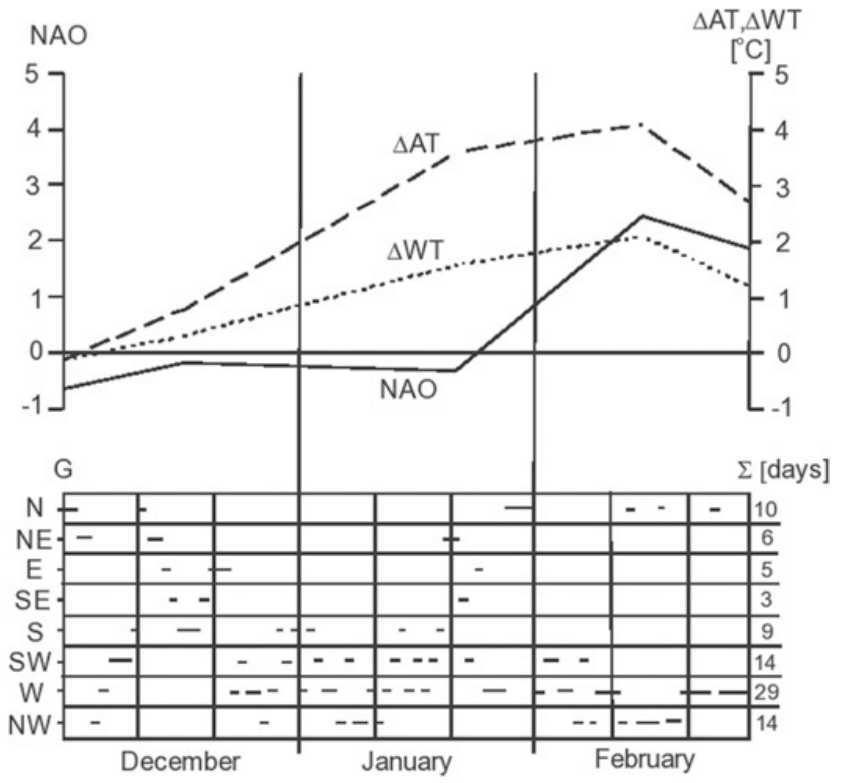

Fig. 3. Synchronized progress of the North Atlantic Oscillation Index $(\mathrm{NAO})$, the water temperature anomaly $(\Delta \mathrm{WT})$ in Lake Leba, air temperature anomaly $(\triangle \mathrm{AT})$ in Leba and number of days with geostrophic wind directions $(\mathrm{G})$ at the southern Baltic Sea during the very mild winter 1997/1998.

$\left(\mathrm{NAO}_{\text {Jan }} v s . \mathrm{WT}_{\mathrm{May}}\right)$. Even at a time lag of three months, the relationships $\left(\mathrm{NAO}_{\text {Jan }}\right.$ vs. $\left.\mathrm{WT}_{\mathrm{Apr}}\right)$ were significant (even at $\alpha=0.01$ ).

Variability in the correlation coefficients for increasingly longer time lags between the January value of the predictive variable $\left(\mathrm{NAO}_{\mathrm{Jan}}\right)$ and the later values of the response variable $\left(\mathrm{WT}_{\mathrm{Feb}, \mathrm{Mar}, \ldots, \mathrm{Dec}}\right)$ in the Jamno, Gardno and Lebsko are shown in Figure 4. Obviously, the strongest correlations were the synchronous ones $\left(\mathrm{NAO}_{\text {Jan }} v s . \mathrm{WT}_{\mathrm{Jan}}\right)$. The relationship lost its significance at time lags longer than three months ( $\left.\mathrm{WT}_{\mathrm{May}, \mathrm{Jun}, . ., \mathrm{Dec}}\right)$.

Significant asynchronous relationships with time lags of one month involved also the NAO Indices for February $\left(\mathrm{NAO}_{\mathrm{Feb}} v s . \mathrm{WT}_{\mathrm{Mar}}\right)$, May $\left(\mathrm{NAO}_{\text {May }} v s . \mathrm{WT}_{\text {Jun }}\right)$, October $\left(\mathrm{NAO}_{\mathrm{Oct}}\right.$ vs. $\left.\mathrm{WT}_{\mathrm{Nov}}\right)$, and November $\left(\mathrm{NAO}_{\mathrm{Nov}}\right.$ vs. $\left.\mathrm{WT}_{\text {Dec }}\right)$. However, the relationships lost their significance at longer time lags (Table 4).

Except for summer and April, both the synchronous and asynchronous relationships produced positive correlation and regression coefficients (Tables 3 and 4). This means that an increase in the NAO Index was accompanied by an increase in water temperature in the three coastal lakes. The highest water temperature increase induced by an increase in the NAO Index occurred in winter.

Asynchronous seasonal relationships were slightly stronger than the monthly ones. Significant asynchronous relationships concern mostly winter, when NAO refers to the period of December-February and WT was measured in individual winter months as well as in March and April. The relevant correlation coefficients ranged from $0.32\left(\mathrm{NAO}_{\text {Dec-Feb }}\right.$ vs. $\left.\mathrm{WT}_{\mathrm{XII}}\right)$ in Lake Lebsko to 0.62
Table 4. Linear correlation coefficients of water temperature in coastal lakes of the southern Baltic Sea with the previous one (A), two (B) and three (C) months of the NAO Index values (1961-2000).

\begin{tabular}{|c|c|c|c|}
\hline Variables & Jamno & Gardno & Łebsko \\
\hline & A & & \\
\hline $\mathrm{NAO}_{\text {Dec }} \mathrm{WT}_{\text {Jan }}$ & $0.343^{*}$ & 0.249 & 0.304 \\
\hline $\mathrm{NAO}_{\mathrm{Jan}} \mathrm{WT}_{\mathrm{Feb}}$ & $0.474 * *$ & $0.431 * *$ & 0.470 ** \\
\hline $\mathrm{NAO}_{\mathrm{Feb}} \mathrm{WT}_{\mathrm{Mar}}$ & $0.580 * *$ & $0.539 * *$ & $0.574 * *$ \\
\hline $\mathrm{NAO}_{\mathrm{Mar}} \mathrm{WT}_{\mathrm{Apr}}$ & 0.016 & 0.070 & 0.088 \\
\hline $\mathrm{NAO}_{\text {Apr }} \mathrm{WT}_{\text {May }}$ & -0.205 & -0.260 & -0.127 \\
\hline $\mathrm{NAO}_{\text {May }} \mathrm{WT}_{\text {Jun }}$ & $0.474 * *$ & $0.562 * *$ & 0.285 \\
\hline $\mathrm{NAO}_{\text {Jun }} \mathrm{WT}_{\mathrm{Jul}}$ & -0.138 & -0.151 & -0.079 \\
\hline $\mathrm{NAO}_{\text {Jul }} \mathrm{WT}_{\mathrm{Aug}}$ & 0.144 & 0.142 & 0.204 \\
\hline $\mathrm{NAO}_{\text {Aug }} \mathrm{WT}_{\text {Sept }}$ & -0.002 & 0.013 & 0.061 \\
\hline $\mathrm{NAO}_{\text {Sept }} \mathrm{WT}_{\text {Oct }}$ & 0.181 & 0.236 & 0.178 \\
\hline $\mathrm{NAO}_{\text {Oct }} \mathrm{WT}_{\mathrm{Nov}}$ & $0.488 * *$ & $0.442 * *$ & $0.400 *$ \\
\hline \multirow{2}{*}{$\mathrm{NAO}_{\text {Nov }} \mathrm{WT}_{\text {Dec }}$} & 0.230 & $0.412 * *$ & $0.315^{*}$ \\
\hline & $\mathrm{B}$ & & \\
\hline $\mathrm{NAO}_{\text {Nov }} \mathrm{WT}_{\text {Jan }}$ & 0.018 & 0.021 & 0.024 \\
\hline $\mathrm{NAO}_{\text {Dec }} \mathrm{WT}_{\mathrm{Feb}}$ & 0.086 & 0.003 & 0.035 \\
\hline $\mathrm{NAO}_{\text {Jan }} \mathrm{WT}_{\mathrm{Mar}}$ & $0.420 * *$ & $0.486^{* *}$ & $0.421 * *$ \\
\hline $\mathrm{NAO}_{\mathrm{Feb}} \mathrm{WT}_{\mathrm{Apr}}$ & 0.154 & 0.274 & $0.350 *$ \\
\hline $\mathrm{NAO}_{\text {Mar }} \mathrm{WT}_{\text {May }}$ & 0.310 & $0.319^{*}$ & $0.358 *$ \\
\hline $\mathrm{NAO}_{\text {Apr }} \mathrm{WT}_{\text {Jun }}$ & 0.038 & 0.043 & 0.138 \\
\hline $\mathrm{NAO}_{\text {May }} \mathrm{WT}_{\mathrm{Jul}}$ & 0.194 & 0.237 & 0.148 \\
\hline $\mathrm{NAO}_{\text {Jun }} \mathrm{WT}_{\text {Aug }}$ & -0.065 & -0.149 & -0.171 \\
\hline $\mathrm{NAO}_{\mathrm{Jul}} \mathrm{WT}_{\text {Sept }}$ & 0.104 & 0.009 & 0.125 \\
\hline $\mathrm{NAO}_{\text {Aug }} \mathrm{WT}_{\text {Oct }}$ & -0.081 & -0.101 & -0.030 \\
\hline $\mathrm{NAO}_{\text {Sept }} \mathrm{WT}_{\mathrm{Nov}}$ & 0.114 & 0.174 & 0.177 \\
\hline \multirow[t]{2}{*}{$\mathrm{NAO}_{\text {Oct }} \mathrm{WT}_{\text {Dec }}$} & -0.084 & -0.077 & -0.085 \\
\hline & $\mathrm{C}$ & & \\
\hline $\mathrm{NAO}_{\text {Oct }} \mathrm{WT}_{\text {Jan }}$ & -0.184 & -0.220 & -0.165 \\
\hline $\mathrm{NAO}_{\mathrm{Nov}} \mathrm{WT}_{\mathrm{Feb}}$ & -0.023 & -0.060 & -0.078 \\
\hline $\mathrm{NAO}_{\text {Dec }} \mathrm{WT}_{\mathrm{Mar}}$ & 0.069 & 0.207 & 0.185 \\
\hline $\mathrm{NAO}_{\text {Jan }} \mathrm{WT}_{\mathrm{Apr}}$ & $0.511^{* *}$ & $0.509 * *$ & $0.523^{* *}$ \\
\hline $\mathrm{NAO}_{\mathrm{Feb}} \mathrm{WT}_{\text {May }}$ & 0.035 & 0.173 & 0.182 \\
\hline $\mathrm{NAO}_{\text {Mar }} \mathrm{WT}_{\text {Jun }}$ & 0.165 & 0.202 & $0.322 *$ \\
\hline $\mathrm{NAO}_{\mathrm{Apr}} \mathrm{WT}_{\mathrm{Jul}}$ & -0.087 & -0.004 & -0.032 \\
\hline $\mathrm{NAO}_{\text {May }} \mathrm{WT}_{\text {Aug }}$ & -0.082 & -0.106 & -0.287 \\
\hline $\mathrm{NAO}_{\text {Jun }} \mathrm{WT}_{\text {Sept }}$ & 0.019 & 0.051 & -0.022 \\
\hline $\mathrm{NAO}_{\text {Jul }} \mathrm{WT}_{\text {Oct }}$ & -0.233 & -0.276 & -0.129 \\
\hline $\mathrm{NAO}_{\text {Aug }} \mathrm{WT}_{\text {Nov }}$ & -0.295 & -0.241 & -0.128 \\
\hline $\mathrm{NAO}_{\text {Sept }} \mathrm{WT}_{\text {Dec }}$ & -0.083 & -0.041 & -0.029 \\
\hline
\end{tabular}

*Values significant at the level $\alpha=0.05$.

$* *$ Values significant at the level $\alpha=0.01$.

$\left(\mathrm{NAO}_{\text {Dec-Feb }} v s . \mathrm{WT}_{\mathrm{Jan}}\right)$ in Lake Jamno. It is noteworthy that these monthly WT values concerned the period of December-February $\left(\mathrm{NAO}_{\text {Dec-Feb }}\right)$. On the other hand, for WT from beyond this period, i.e., for March and April, correlation coefficients ranged from $0.44\left(\mathrm{NAO}_{\text {Dec-Feb }} v s\right.$. $\left.\mathrm{WT}_{\mathrm{Apr}}\right)$ to $0.61\left(\mathrm{NAO}_{\text {Dec-Feb }} v s . \mathrm{WT}_{\mathrm{Mar}}\right)$ in Lake Gardno. In January-April, the coefficients were therefore very similar. Fairly strong relationships in March and April may have been explained by thermal inertia, especially that of the Baltic water. The Baltic water, of a volume larger than that of the lakes, is more prone to "remember" 
a

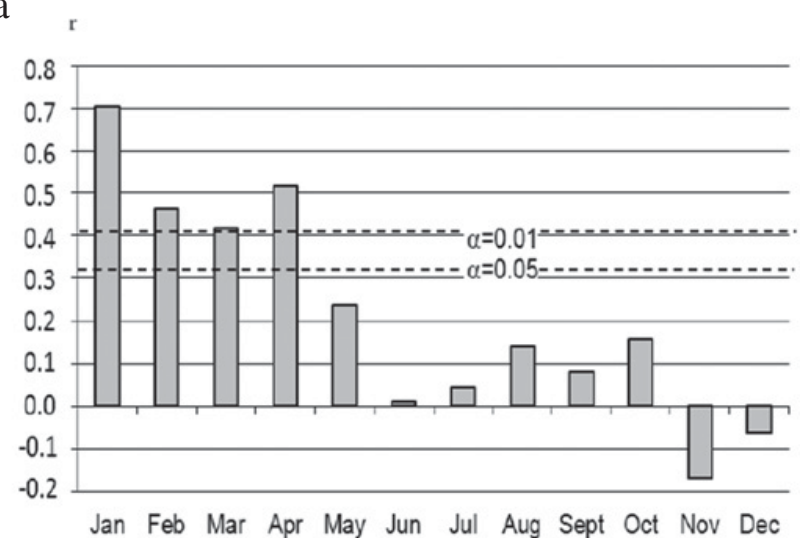

b

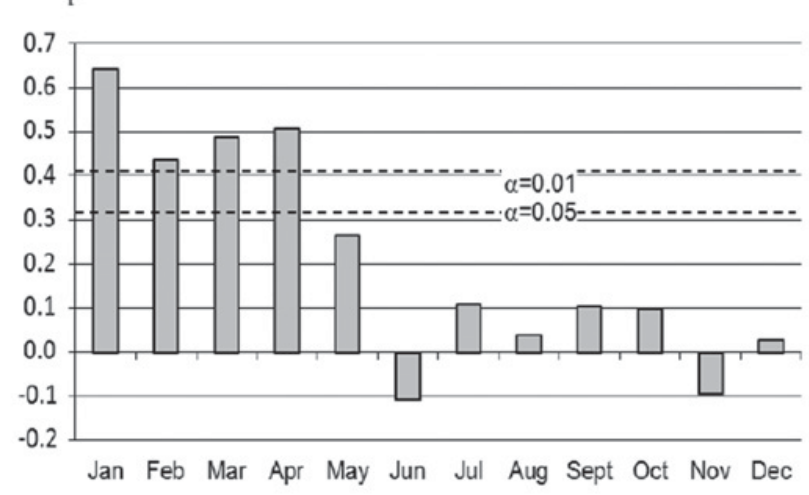

c

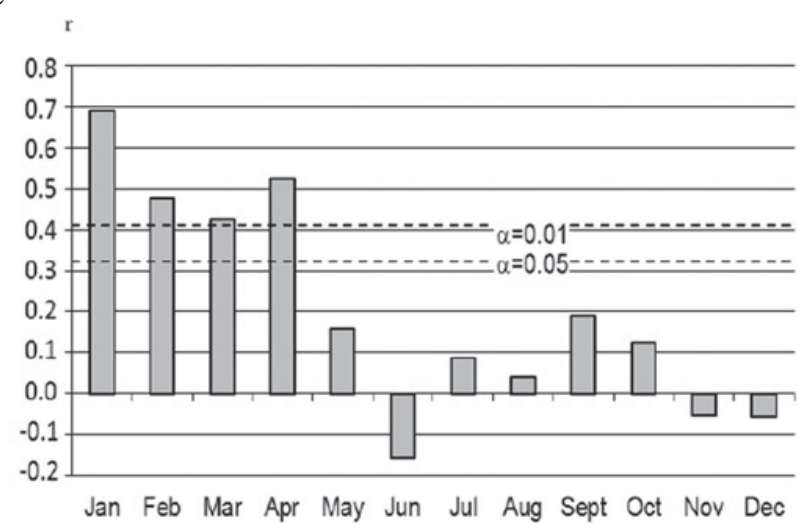

Fig. 4. Linear correlation coefficients $(r)$ of the water temperature in coastal lakes: Jamno (a), Gardno (b) and Lebsko (c) in months with the North Atlantic Oscillation Index in January (19612000).

winter thermal conditions $\left(\mathrm{NAO}_{\mathrm{Dec}-\mathrm{Feb}}\right)$ and later, indirectly, affect the thermal regime of the shallow lakes studied.

Some asynchronous autumn relationships $\left(\mathrm{NAO}_{\mathrm{Sept}-}\right.$ Nov) were found to be significant for November $\left(\mathrm{WT}_{\mathrm{Nov}}\right)$, February (WT $\mathrm{Web}_{\mathrm{Fe}}$ ), March (WT $\left.\mathrm{War}_{\mathrm{Mar}}\right)$ and August $\left(\mathrm{WT}_{\mathrm{Aug}}\right)$. Relationships with WT beyond autumn produced negative correlation coefficients which ranged from -0.33
$\left(\mathrm{NAO}_{\text {Sept-Nov }} v s . \mathrm{WT}_{\mathrm{Feb}}\right)$ in the Jamno to -0.48 $\left(\mathrm{NAO}_{\text {Sept-Nov }} v s . \mathrm{WT}_{\text {Mar }}\right)$ in the Lebsko. It is difficult to explain why thermal conditions of autumn $\left(\mathrm{NAO}_{\mathrm{Sept}-\mathrm{Nov}}\right)$ inversely affect the thermal regime in the lakes in, e.g., February $\left(\mathrm{WT}_{\mathrm{Feb}}\right)$ and March ( $\left.\mathrm{WT}_{\mathrm{Mar}}\right)$. However, the analysis of air temperature revealed that, frequently a warm autumn was followed by a cold winter, and vice versa, a cool autumn was followed by mild winter. Such relationships may be translated into the thermal regimes of the shallow coastal lakes discussed in this study. On the other hand, no significant relationships between NAO and WT with exclusively seasonal values could be revealed for the lakes studied.

\section{Discussion and concluding remarks}

Effects of NAO on climatic conditions of Europe are commonly known. NAO affects thermal variables fairly strongly, particularly the air temperature (Rogers and van Loon, 1979; Hurrell and van Loon, 1997; Marshall et al., 2001) and ice conditions (Koslowski and Glaser, 1999; Omstedt and Chen, 2001; Jevrejeva, 2002; George, 2007). NAO affects a large part of the northern hemisphere from the eastern seaboard of the US to Siberia, and from the Arctic to the subtropical Atlantic Ocean; the effects involve the entire troposphere, particularly in winter (Wallace and Gutzler, 1981; Marshall et al., 2001; Hurrell et al., 2003).

NAO forms statistically significant relationships with water temperature as well. In the southern Baltic's Gdańsk Deep, the December-March NAO Indices (NAO Dec-Mar $_{\text {) }}$ were found to be significantly correlated with sea water temperature in February, March, April, and May, the respective correlation coefficients being $0.53 ; 0.68 ; 0.63$; and 0.37 (Marsz and Styszyńska, 2003). Somewhat stronger relationships between the NAO Index and water temperature are observed in the coastal zone. In December-March, the correlation coefficients were found to range from 0.74 in the western part of the coastal Baltic zone (Świnoujście) to 0.81 in the eastern part (Władysławowo; Girjatowicz, 2008). However, the correlation coefficients in the December-February in the coastal lakes were found to range from 0.70 (Lake Łebsko) to 0.74 (Lake Gardno).

The shallow Baltic coastal lakes, as polymictic water bodies, respond rapidly to the North Atlantic Oscillation. Their water temperature is fairly strongly correlated with the NAO Index, but only in the cold part of the year. On the other hand, similar relationships may become visible in dimictic lakes, particularly in their deeper layers, in later periods. According to Livingstone (1993), in thermally stratified lakes, a climatic signal recorded in spring may be maintained in the hypolimnion for a few months. As reported by Gerten and Adrian (2001), the NAO signal in a deep dimictic lake persists in the hypolimnion until the next winter. These are the lakes in which the water column mixes fully twice a year (the spring and autumn circulation). 
The NAO Index was positively correlated with water temperature in late autumn and winter. The correlation was mainly a result of a frequent advection of polarmaritime air masses from the North Atlantic. In autumn and winter, those masses are warm and induce an increase in the water temperature. A reverse effect is observed in summer when the land is strongly heated and the cool polar-maritime air masses decrease the water temperature. Although the relationships concerning the lakes studied proved mostly non-significant, the negative correlation and regression coefficients signal a cooling effect of those air masses in summer.

The strongest effects of the Atlantic air masses on water temperature are observed in winter when the solar radiation is substantially reduced. Thermal conditions at higher latitudes are controlled in that season by the heat accumulated in the Atlantic and transported by circulation-related factors (Shuleykin, 1968; Glagoleva and Skriptunova, 1979; Skriptunova, 1984). Consequently, the relationships are at their strongest in January and February, and weaken rapidly thereafter to become non-significant as early as in April. This is evidence of a weakening effect of atmospheric circulation (NAO) and intensifying influence of local conditions (solar factors, wind speed and direction) on water temperature of the lakes during spring and summer. Similar patterns were reported from other lakes (Livingstone and Dokulil, 2001; George et al., 2004b).

The strong relationships between water temperature and the NAO Index in the southern Baltic coastal lakes are associated with relatively mild ice conditions in those lakes, compared with ice conditions prevailing in midcontinental lakes. In winter, the lakes studied experience the warming effect of the sea and the ocean; therefore, periods without ice are not infrequently recorded during the ice season. The water in the lakes in winter is often affected by air masses advecting from the Atlantic. Consequently, the water temperature variations depend strongly on the temperature of the advecting air masses. On the other hand, under more severe climatic conditions, relationships between the water temperature in a lake and the NAO Index are much weaker. The long-lasting ice cover in those lakes isolates the water from oceanic influences (NAO). Consequently, relationships between the water temperature and the NAO index will be weaker or even non-significant. Nõges (2004) reported nonsignificant relationships between water temperature and the NAO Index in winter for Lake Vorrtsjärv with a prolonged ice season.

Asynchronous relationships do present a certain predictive potential. The NAO Index in January (NAO Jan) was significantly correlated with the lakes' water temperature until April $\left(\mathrm{WT}_{\mathrm{Apr}}\right)$. Slightly stronger relationships covering a longer time span were observed in the southern Baltic coastal zone (Girjatowicz, 2008). The difference in the strength of the relationship could have been related to differences in the thermal inertia of the water areas compared. Larger areas (seas and oceans) show a high thermal inertia (the so-called "thermal memory"). These "remembered", retained effects of an earlier atmospheric circulation may be produced after a time lag. The heat accumulated in the water is gradually transmitted to the atmosphere via exchange processes, which are most intensive in winter at higher latitudes (Lamb, 1978; Ugryumov, 1981; Abuzyarov et al., 1988). In contrast, the NAO signal in the southern Baltic coastal lakes (polymictic lakes) persists for a very short time only. Therefore, the asynchronous relationships are much weaker, and are usually non-significant for extended (longer than one month) prognostic periods of time. According to Gerten and Adrian (2000), a climatic signal in shallow, non-stratified lakes persists for a short time only.

Most probably, the intensive atmospheric circulation (NAO) in January exerts a substantial effect on the strong relationships between the NAO Index and WT in that month. The intensive flow of the air masses from the Atlantic strongly impacts the thermal conditions of lakes and the entire southern Baltic. In winter, particularly in January, weather conditions (NAO) are most efficiently "remembered" (encoded) by the water of the lakes studied, and particularly so by water in deeper southern Baltic areas. The thermal conditions of these waters, shaped by atmospheric forcing particularly in January, should be reflected in later months. The shallow coastal lakes are characterized by thermal inertia lower than that of the Baltic water. Therefore, it should be presumed that the Baltic, with its higher thermal inertia ("thermal memory") will affect the thermal conditions in the lakes later on as well. The effects may be climatic in nature (exchange of air masses) and/or hydrographic (exchange of water via straits).

The processes presented may explain the high correlation coefficients of the winter asynchronous relationships presented here, particularly for January. It is clear that the strongest correlation coefficients involve adjacent months rather than months that are farther apart in time. On the other hand, difficult to explain are certain fairly strong correlations for non-winter months, e.g., $\mathrm{NAO}_{\text {May }} v s$. $\mathrm{WT}_{\text {Jun }}, \mathrm{NAO}_{\text {Oct }} v s . \mathrm{WT}_{\text {Nov }}$, and $\mathrm{NAO}_{\text {Jan }} v s . \mathrm{WT}_{\mathrm{Apr}}$.

It is interesting that stronger correlation coefficients in the asynchronous relationships with the NAO Index in January involve April $\left(\mathrm{NAO}_{\mathrm{Jan}} \mathrm{WT}_{\mathrm{Apr}}\right)$ rather than February $\left(\mathrm{NAO}_{\mathrm{Jan}} \mathrm{WT}_{\mathrm{Feb}}\right)$ and March $\left(\mathrm{NAO}_{\mathrm{Jan}} \mathrm{WT}_{\mathrm{Mar}}\right)$. Most probably, the strong and time-lagged correlation is a result of the influence exerted by the Baltic water in which effects of the January atmospheric circulation $\left(\mathrm{NAO}_{\mathrm{Jan}}\right)$ are "remembered" (accumulated) in deeper water layers. The southern Baltic coast relatively frequently experiences easterly winds in spring, which enhance upwelling of cold water from deeper layers and may be one of indirect causes of the strong correlations in April $\left(\mathrm{NAO}_{\text {Jan }} \mathrm{WT}_{\text {Apr }}\right)$.

The water temperature in the shallow lakes which respond relatively rapidly to thermal conditions of the air (atmospheric circulation) can be expected to be more strongly correlated with the NAO Index than the temperature of the coastal sea areas. However, the shallow 
lakes in question also respond relatively rapidly to solar conditions and to sea water intrusions which diminish the strength of the NAO effect on water temperature. Presumably, stronger relationships would be obtained with additional independent (prognostic) variables involving solar conditions and/or sea water intrusions in multiple regression equations. However, the paucity of relevant data prevents further investigation of this phenomenon.

Acknowledgements. The author would like to express his gratitude to Professor Andrzej Witkowski, Ph.D., D.Sc. and Dr Teresa Radziejewska, both of the University of Szczecin, and to Dr Colin Archibald of Durban, Republic of South Africa, for their linguistic assistance during preparation of the manuscript. Thanks are due to two anonymous reviewers whose comments greatly improved the manuscript.

\section{References}

Abuzyarov Z.K., Kudryavaya K.I., Seryakov J.I. and Skriptunova L.I., 1988. Marine Forecasting, Gidrometeoizdat, Leningrad (in Russian).

Alenius P. and Makkonen L., 1981. Variability of the annual maximum ice extent of the Baltic Sea. Arch. Meteorol. Geophys. Bioklimatol. Ser. B, 29, 393-398.

Arhonditsis G.B. and Brett M.T., 2004. Effects of climatic variability on the thermal properties of Lake Washington. Limnol. Oceanogr., 49, 256-270.

Barnston A.G. and Livezey R.E., 1987. Classification seasonality and persistence of low-frequency atmospheric circulation patterns. Mon. Weather Rev., 115, 1083-1126.

Choiński A., 1995. Outline of physical limnology of Poland, Wydawnictwo Naukowe Uniwersytetu im. A. Mickiewicza, Poznań (in Polish).

Cyberski J., 1984. Water resources of river basin. In: Augustowski B. (ed.), The Pomeranian littoral zone, Ossolineum, Gdańsk, 189-213 (in Polish).

Cyberski J. and Jędrasik J., 2000. Water exchange processes in coastal lakes of southern Baltic for Sea Gardno Lake. Inżynieria Morska i Geotechnika, 6, 319-324 (in Polish).

D’Odorico P., Yoo J.C. and Jaeger S., 2002. Changing Seasons: An Effect of the North Atlantic Oscillation? J. Climate, 15, 435-445.

Drwal J. and Cieśliński R., 2007. Coastal lakes and marine intrusions on the Southern Baltic coast. Oceanological and Hydrobiological Studies, 36, 61-75.

Environmental conditions in the Polish zone of the southern Baltic Sea, 1986-2000. Materiały Instytutu Meteorologii i Gospodarki Wodnej, Gdynia (in Polish).

George D.G., 2007. The impact of the North Atlantic Oscillation on the development of ice on Lake Windermere. Clim. Change, 81, 455-468.

George D.G., Järvinen M. and Arvola L., 2004a. The influence of the North Atlantic Oscillation on the winter characteristics of Windermere (UK) and Pääjärvi (Finland). Boreal Environment Research, 9, 389-399.

George D.G., Maberly S.C. and Hewitt D.P., 2004b. The influence of the North Atlantic Oscillation on the physical, chemical and biological characteristcs of four lakes in the English Lake District. Freshw. Biol., 49, 760-774.

Gerten D. and Adrian R., 2000. Climate-driven changes in spring plankton dynamics and the sensitivity of shallow polimictic lakes to the North Atlantic Oscillation. Limnol. Oceanogr., $45,1058-1066$

Gerten D. and Adrian R., 2001. Differences in the persistency of the North Atlantic Oscillation signal among lakes. Limnol. Oceanogr., 46, 448-455.

Girjatowicz J.P., 2003. Ice conditions in coastal lakes of the southern Baltic Sea. Ann. Limnol. - Int. J. Lim., 39, 317-331.

Girjatowicz J.P., 2006. Spatial differentiation of water temperature along Polish Coast. Czasopismo Geograficzne, 77, 255269 (in Polish).

Girjatowicz J.P., 2008. The relationships of the North Atlantic Oscillation to water temperature along the southern Baltic Sea Coast. Int. J. Climatol., 28, 1071-1081.

Glagoleva M.G. and Skriptunova L.I., 1979. Forecast of water temperature in ocean, Gidromietieoizdat, Leningrad (in Russian).

Hurrell J.W., 1995. Decadal trends in the North Atlantic Oscillation: Regional temperatures and precipitation. Science, 269, 676-679.

Hurrell J.W., 1996. Influence of variations in extratropical wintertime teleconnections on Northern Hemisphere temperatures. Geophys. Res. Let., 23, 665-668.

Hurrell J.W. and van Loon H., 1997. Decadal variations in climate associated with the North Atlantic Oscillation. Clim. Change, 36, 301-326.

Hurrell J.W., Kushnir Y., Ottersen G. and Visbeck M., 2003. An Overview of the North Atlantic Oscillation. In: Hurrell J.W., Kushnir Y., Ottersen G. and Visbeck M. (eds.), The North Atlantic Oscillation, Geophysical Monograph Series, 134, $1-36$.

Jaagus J., 2006. Trends in sea ice conditions in the Baltic Sea near the Estonian coast during the period 1949/1950-2003/2004 and their relationships to large-scale atmospheric circulation. Boreal Environment Research, 11, 169-183.

Jańczak J., 1997. Atlas of Polish Lakes, Bogucki Wydawnictwo Naukowe, Poznań (in Polish).

Jevrejeva S., 2002. Association between the ice conditions in the Baltic Sea along the Estonian Coast and the North Atlantic Oscillation. Nordic Hydrology, 33, 319-330.

Jevrejeva S., Drabkin V.V., Kostjukov J., Lebedev A.A., Lepparänta M., Mironov Ye.U., Schmelzer N. and Sztobryn M., 2004. Baltic Sea ice seasons in the twentieth century. Climate Res., 25, 217-227.

Jones P.D., Jonsson T. and Wheeler D., 1997. Extension to the North Atlantic Oscillation using early instrumental pressure observations from Gibraltar and south-west Iceland. Int. J. Climatol., 17, 1433-1450.

Kondracki J., 1998. Regional Geography of Poland, Wydawnictwo Naukowe PWN, Warszawa (in Polish).

Koslowski G. and Glaser R., 1999. Variations in reconstructed ice winter severity in the western Baltic from 1501 to 1995 and their implications for the North Atlantic Oscillation. Clim. Change, 41, 175-191.

Koslowski G. and Loewe P., 1994. The western Baltic sea ice season in terms of mass-related severity index 1879-1992. Part I: Temporal variability and association with the North Atlantic Oscillation. Tellus, 46A, 66-74. 
Kozłowska-Szczęsna T., 1997. Mean monthly air temperature. In: Atlas of the Republic of Poland, Polish Academy of Sciences, Warszawa (in Polish).

Kożuchowski K., 1996. Secular changes of the Baltic Sea cover (1720-1992). Przeglad Geograficzny, 3-4, 445-455 (in Polish).

Lamb H.H., 1978. Climate: Present, Past and Futur, Methuen, London.

Livingstone D.M., 1993. Temporal structure in the deepwater temperature of four Swiss lakes: a short-term climatic changes indicator? Verh. Internat. Verein. Limnol., 25, 75-81.

Livingstone D.M., 2003. Impact of secular climate change on the thermal structure of a large temperate central European lake. Clim. Change, 57, 205-225.

Livingstone D.M. and Dokulil M.T., 2001. Eighty years of spatially coherent Austrian lake surface temperatures and their relationship to regional air temperature and the North Atlantic Oscillation. Limnol. Oceanogr., 46, 1220-1227.

Lorenc H., 2005. Atlas of climate of Poland, Wydawnictwo Instytutu Meteorologii i Gospodarki Wodnej, Warszawa (in Polish).

Magnuson J.J., Robertson D.M., Benson B.J., Wynne R.H., Livingstone D.M., Arai T., Assel R.A., Barry R.G., Card V., Kuusisto E., Granin N.G., Prowse T.D., Steward K.M. and Vuglinski V.S., 2000. Historical trends in lake and river ice cover in the Northern Hemisphere. Science, 289, 1743-1746.

Maher O.A., Uvo C.B. and Bengtsson L., 2005. Comparison between Two Extreme NAO Winters and Consequences on the Thermal Regime of Lake Vendyurskoe, Karelia. $J$. Hydrometeorol., 6, 775-783.

Majewski A., 1972. Hydrological characteristic of the Polish coast estuarine waters. Prace Państwowego Instytutu Hydrologiczno-Meteorologicznego, 105, 3-40 (in Polish).

Majewski A., 1987. Characteristics of the southern Baltic Waters. In: Augustowski B. (ed.), The Baltic Southern, Ossolineum, Gdańsk, 173-217 (in Polish).

Marshall J., Kushnir Y., Battisti D., Chang P., Hurrell J., McCartney M. and Visbeck M., 1997. Atlantic climate variability ('white paper'), http://geoid.mit.edu/accp/ avehtml.html.

Marshall J., Kushnir Y., Battisti D., Chang P., Czaja A., Dickson R., Hurrell J., McCartney M., Saravanan R. and Visbeck M., 2001. North Atlantic climate variability: phenomena, impacts and mechanisms. Int. J. Climatol., 21, 1863-1898.

Marsz A.A., 1999. The North Atlantic Oscillation and the thermal regime of waters in the area of north-west Poland and the Polish coast of the Baltic Sea. Przeglad Geograficzny, 71, 225-245 (in Polish).

Marsz A.A. and Styszyńska A., 2003. Changes in Baltic surface temperature in the Gulf region and Gdańsk Deep (18711992) and their relationships with air temperature. Prace Wydzialu Nawigacyjnego, Akademii Morskiej w Gdyni, 14, 109-137 (in Polish).

Miętus M., 1994. Vector of geostrophic wind in the Baltic Sea region as an index of local circulation and its relationship to hydro-meteorological characteristics along the Polish coast. In: Heino R. (ed.), Proceedings of the European Workshop on Climate Variations, Majvik, Finland, SILMU, 278-292.
Miętus M., 2000. The calendar of local atmospheric circulation index in the southern Baltic Sea region 1961-2000, Wydawnictwo Instytutu Meteorologii i Gospodarki Wodnej, Gdynia (in Polish).

Mikulski Z., 1964. Water balace of Baltic gulfs. Wiadomości Stużby Hydrologicznej i Meteorologicznej, 59a, 3-61 (in Polish).

Mikulski Z., 1970. Inland waters in the coastal zone of the southern Baltic Sea. Prace Państwowego Instytutu Hydrologiczno-Meteorologicznego, 98, 25-45 (in Polish).

Nõges T., 2004. Relation of the changes of the North Atlantic Oscillation Index and the Gulf Stream Position Index in the hydrology and phytoplankton of Võrtsjärv, a large, shallow lake in Estonia. Boreal Environment Research, 9, 401-407.

Nõges T., 2006. Consequences of changed nutrient loading and climate changes on the ecological status of large, shallow, temperate lakes Võrtsjärv and Peipsi, Estonia, European Large Lakes Symposium, 11-15 September, 2006, Tartu, Estonia.

Omstedt A. and Chen D., 2001. Influence of atmospheric circulation on the maximum ice extent in the Baltic Sea. $J$. Geophys. Res., 106, 4493-4500.

Peeters F. and Livingstone D.M., 2002. Modeling 50 years of historical temperature profiles in a large central European lake. Limnol. Oceanogr., 47, 186-197.

Rogers J.C. and van Loon H., 1979. The seesaw in winter temperatures between Greenland and northern Europe. Mon. Weather Rev., 107, 509-519.

Shuleykin W.W., 1968. Physics marine, Izdatelstvo, Nauka, Moskva (in Russian).

Skriptunova L.I., 1984. Methods of hydrological marine forecasts, Gidromietieoizdat, Leningrad (in Russian).

Straile D., Livingstone D.M., Weyhenmeyer G.A. and George D.G., 2003. The North Atlantic Oscillation: climatic significance and environmental impact. Geophysical Monograph, 134, 263-279.

Szmidt K., 1967. The role of the Baltic in the hydrographic relations of the coastal lakes. Zeszyty Geograficzne Wyższej Szkoły Pedagogicznej, 9, 47-76 (in Polish).

Ugryumov A.I., 1981. Thermal regim of ocean and long-term weather forecast, Gidromietieoizdat, Leningrad (in Russian).

Walker G.T., 1924. Correlations in seasonal variations of weather. IX Memoirs India Meteorological Department, 24, 275-332.

Wallace J.M. and Gutzler D.S., 1981. Teleconnections in the geopotential height field during the Northen Hemisphere winter. Mon. Weather Rev., 109, 784-812.

Weyhenmeyer G.A., 2004. Synchrony in relationships between the North Atlantic Oscillation and water chemistry among Sweden's largest lakes. Limnol. Oceanogr., 49, 11911201.

Wibig J., 2001. The influence of the atmospheric circulation on spatial distribution of temperature and precipitation anomaly in Europe, Wydawnictwo Uniwersytetu Łódzkiego, Łódź (in Polish).

Wiszniewski W., 1973. Climatological atlas of Poland, Państwowe Przedsiębiorstwo Wydawnictw Kartograficznych, Warszawa (in Polish). 